\title{
The Engineering Education in China, Compared to Pakistan, Europe, and the USA, in Prospects of One Belt, One Road
}

\author{
Abdul Sami Channa ${ }^{1,2}$, Farrukh Raza Amin ${ }^{1,2}$, Guangqing Liu ${ }^{1,2} \&$ Chang Chen ${ }^{1,2}$ \\ ${ }^{1}$ College of Chemical Engineering, Beijing University of Chemical Technology, Beijing 100029, P.R. China \\ ${ }^{2}$ School of International Education, Beijing University of Chemical Technology, Beijing 100029, P.R. China \\ Correspondence: Chang Chen, College of Chemical Engineering, Beijing University of Chemical Technology, \\ 15 North $3^{\text {rd }}$ Ring East Road, Beijing 100029, China. Tel: 86-10-6444-2375. E-mail: \\ chenchang@mail.buct.edu.cn
}

Received: April 27, 2018

Accepted: June 04, 2018

Online Published: June 25, 2018

doi:10.5539/hes.v8n3p15

URL: https://doi.org/10.5539/hes.v8n3p15

\begin{abstract}
Engineering representing the backbone of a nation aims to migrate towards the knowledge economy. The strengthening of engineering education leads to the nation's self-reliance while building indigenous capabilities. The current study attempts to compare engineering education in China with Pakistan, Europe, and the USA in context of One Belt, One Road (OBOR) initiative. The comparison provided by this study will help to identify some of the trends and challenges in engineering education at the national and regional level of OBOR countries. The study suggests that OBOR strategy will allow China to build excellence in engineering education and export its expertise among the member countries during developing stage.
\end{abstract}

Keywords: accreditation, comparison, expenditure, engineering education, GDP, ranking

\section{Introduction}

Engineering is the application of science and mathematics to solve problems, figure out how things work and find practical applications of scientific discoveries. Scientists work for innovations that ease human life, but the engineers are responsible for making those innovations available to the world (Lucas, 2014). Therefore, strengthening of engineering education and research leads to national self-reliance by developing indigenous capabilities (Rahman, 2011). In different geographical parts of the world, it is varying in pace, instruction, and learning strategies (Alves, Kahlen, Flumerfelt, \& Manalang, 2013). The highly successful engineering programs can be assessed by providing acceptable preparation of graduates, with broader interdisciplinary training and technological innovations in globally competitive markets (Sonmez, 2014).

Engineering education in the US is technically superior and has been viewed as one of the finest in the world (Bachelors portal, Study Options in the USA). Universities provide the cross-disciplinary and multidisciplinary approaches with proper engineering trainings and true understandings. Moreover, ensures the ability to apply scientific and mathematical knowledge identifying engineering solutions in a global economic, social, and environmental context. Europe being a cultural diversity of different countries provides highly professional standards with proven experience and competency. Instruction paradigm focuses on the development of skills by the dynamic inclusion of students in the learning process, aims to build versatility, free mobility of students and teachers within European (EU) countries (Sonmez, 2014). China with more than 22 million college students, around $1 / 3$ in engineering programs attempts to adopt reform experiences of US and EU countries in engineering education (Fan \& Zhang, 2015). While Pakistan's status in engineering education is still in developing phase. Being signatory of Washington Accord (WA), it is striving hard to align closer with China, Europe, and the US in order to address rising trends of globalization (Memon, Demirdogen, \& Chowdhry, 2009).

The revival of the ancient Chinese Silk Road as OBOR strategy is the biggest story of the physical connection between China, Europe, Western Asia, Southeast Asia and Africa (Yu, 2016). The project will create world's largest platform for economic cooperation, trade and finance collaboration among more than 60 countries (Jinchen, 2016). Large corporations will tap into the region with huge investments will reshape the global trade with the Chinese centered trading network. However, current Chinese engineering education model stems from the former Soviet Union is unable to meet the requirements of advanced industrial practices and seeks academic 
ties with the USA and Europe (Bai et al., 2013). This gap brings the challenges to the academic magnificence of OBOR strategy. Meanwhile, University Ranking Index (URI) is considered as a powerful tool for analyzing the performance of existing individual education system and its status in the global context (Olcay \& Bulu, 2016). Moreover, due to increasing trends of globalization, engineering graduates must be able to work at the transnational level, needs quality of education to meet the global standards and benchmarks.

Therefore, the present study attempts to elaborate the current status of engineering education in China, compared with Pakistan, Europe, and the USA with special reference to OBOR strategy. Meanwhile, different accreditation and assessment systems were adopted by different countries to assure the substantial quality of engineering education (Olcay \& Bulu, 2016). So, the present study also attempts to overview the accreditation systems of aforesaid countries and it will help to promote excellence in engineering education to meet the challenges of globalization.

\section{Engineering Education in China, Pakistan, European Countries and the USA}

\subsection{China}

The Chinese education structure is the biggest state-run education system in the world restrained by Chinese Ministry of Education (MoE). The Higher Education Institutes (HEIs) are broadly viewed as the most esteemed and provide noteworthy learning results to the graduates ( $\mathrm{Li}$ et al., 2011). Being the largest population in the world, China has a massive enrolment of 41.40 million understudies in the year 2015. It had an aggregate of 2879 HEIs, in which 2137 were government, 469 private, 266 independent, and seven runs by Chinese-foreign collaboration till May 2016 (Ministry of Education China, 2016). The engineering education shares 1/3 of the total higher education and bachelor degree program comprises of 4 years (Fan \& Zhang, 2015). Before entering, students have to take 6 years primary, 3 years lower secondary or juniors and 3 years upper secondary or senior high school education (Ryan, 2009). The Higher education in China is managed by central and provincial governments, with the provincial government assuming the main liability. According to the Academic Ranking of World Universities (ARWU) 2015, 10 Chinese universities ranked among top 200, 19 among top 300, 37 among top 400, and 44 among top 500 universities of the world (US News \& World Reports, 2015). The list of top-ranked universities in China on the basis of engineering education with their global ranking is mentioned in Table 1.

Table 1. Top-ranked engineering institutes in China and their global ranking (QS World University Rankings, 2018)

\begin{tabular}{lcc}
\hline Universities Name & Engineering ranking in China & Global engineering ranking \\
\hline Tsinghua University & 1 & 10 \\
Peking University & 2 & 20 \\
Shanghai Jiao Tong University & 3 & 29 \\
Zhejiang University & 4 & 36 \\
Fudan University & 5 & 51 \\
University of Science and Technology China & 6 & 80 \\
Nanjing University & 7 & 97 \\
Xi'an Jiao Tong University & 8 & 145 \\
Harbin Institute of Technology & 9 & 148 \\
Wuhan University & 10 & 152 \\
\hline
\end{tabular}

Although Chinese engineering education system has progressed in the last decade, yet it lacks in technological innovation and creativity. The current engineering education system was adopted from the former Soviet Union is unable to meet the challenges of senior engineering abilities of modern practices. Moreover, the engineering curriculum contains a higher proportion of theoretical contents rather than practical knowledge. Consequently, students lack the adaptation of thinking systematically and engineering design (Bai et al., 2013). In order to overcome these circumstances, China adopted an open-door policy to send more students for studying abroad than any other country. Moreover, it has academic ties with 188 countries and signed agreements of mutual recognition to 47 nations strengthening international exchanges in engineering education, especially with US and EU countries (Zhao, 2017). Additionally, joint educational and research programs are established including student and faculty exchanges with developed countries for mutual sharing of knowledge and practices. The Institute of Tallaght Dublin (ITTD), Ireland and Nanjing University of Technology (NJUT), China deliver a joint bachelor of honors in Mechanical Engineering program to Chinese students. They spend first three years in NJUT China being jointly instructed by ITTD and NJUT teachers and finish their $4^{\text {th }}$ year at Ireland in the same 
class with ITTD students. Chinese students have been shown to have different learning styles than western students. Impressions, assessments and myths about how Chinese students react towards western showing styles are copious and these are frequently in view of obsolete realities. Lecturers delivering modules in NJUT evaluated the student experience in the light of reported cultural differences between Chinese and European students and its impact on the learning and teaching styles (McAuley \& Tiernan, 2012). In 2005, Ecole Normale Supérieure (ENS), Paris, France established sub-campus at the East China Normal University (ECNU) in Shanghai propelling a conjoined Ph.D. study program between two establishments. Furthermore, Hong Kong University of Science and Technology (HKUST), Hua Zhong University of Science and Technology (HZUST) and Tsinghua University (TU), China offer joint engineering program with the Technical University of Munich (TUM), Germany.

The expenditure in the education sector as a level of Gross Domestic Product (GDP) kept up an immediate augmentation from the 1990s to 2012 and raised up to $4 \%$. The $20 \%$ of aggregate spending had been dedicated to higher education (HE) since 1999 (James \& Chen, 2016). The Chinese government raised education spending about 2.2 Trillion Yuan for the year 2012 represented 4.28\% of total GDP. The proportion is not still as much high as the world normal instruction use of GDP to $4.9 \%$. Currently, 25\% of education spending is allocated to HE (Ding \& Zeng, 2015). Moreover, the research and development (R\&D) expenditure is $2.1 \%$ of the total GDP (List of countries by R\&D spending, Wikipedia, 2015). Meanwhile, educational institutes in China can hardly get funding from society. Therefore, demand and supply gap in higher education expenditure still do exist (Jiaju, 2009).

Civil Engineering is the first accredited program in 1990 by the Ministry of Construction (MoC), currently known as Ministry of Housing and Urban-Rural Development (MoHURD) (Jiaju, 2009). Afterward, in 2005 National Coordination Committee of Engineer System Reform (NCCESR) was formed under state council, which was responsible for designing framework of engineering system reforms and conducting accreditation with the consultation of global accrediting bodies. The new accreditation organization Chinese Engineering Education Accreditation Association (CEEAA) under China Association for Science and Technology (CAST) was established, which carried out accreditation of 206 programs in 6 fields of Civil Engineering and 132 programs in other engineering disciplines till 2011 (Jiaju, 2009). Those 351 accredited programs only accounted for 3\% of all the engineering programs in China. Since the program accreditation was comparatively slow and challenging from 1990 to 2011. Meanwhile, after a long way of engineering reforms, China became a full signatory of WA on $2^{\text {nd }}$ June 2016 and CAST was approved as an $18^{\text {th }}$ signatory (Reviewmycdr, 2016). Currently, CEEAA working under CAST is authorized for accreditation of each engineering program in China. Being a largest engineering education country with a vast number of engineering programs and signatory of WA, it has a crucial challenge to meet the quality of engineering education as per international standards.

\subsection{Pakistan}

Pakistan has 188 universities and degree awarding institutes (DAIs) recognized by Higher Education Commission (HEC) in which $60 \%$ are public and rest are planted by the private sector (List of universities in Pakistan, Wikipedia, 2018). Among 188 institutes, around 60\% offer engineering education with more than 30 disciplines (Khattak, 2016). The Bachelor of Engineering comprises 4 years followed by 2 years Master's program. Before entering a Bachelor of Engineering, students must take 5 years of primary education, 5 years secondary followed by 2 years of higher secondary education. The criteria to secure admission in engineering program is highly competitive.

The engineering education in Pakistan has long been criticized for different reasons including inadequate infrastructure, shortage of skilled teaching staff, lack of research facilities, funding, and uneven industry-centric skills. The lack of governance and poor standards of primary education are also paving a major back up to the current circumstances. Therefore, only $7 \%$ of students could reach to engineering universities as per higher education statistics (Memon et al., 2009). However, the educational policies are underway for further improvements. The annual education budget for the year 2016-17 was 2.2\% of total GDP $11 \%$ higher than the last year and R\&D spending was $0.29 \%$ of its total GDP (List of countries by R\&D spending, Wikipedia, 2013). Now, it is planned to boost educational budget up to 4\% of total GDP (Yusufzai, 2016). Among the 188 government, semi-government and private sector universities/institutes/sub-campuses with more than 30 different engineering disciplines, only six Pakistani universities (two in engineering subject) ranked among top 800 universities, according to Quacquarelli Symonds (QS) World University Ranking 2018, as shown in Table 2 (Rankings of Universities in Pakistan, Wikipedia, 2018). 
Table 2. Top-ranked engineering institutes in Pakistan and their global ranking (Rankings of Universities in Pakistan, Wikipedia, 2018)

\begin{tabular}{lcc}
\hline Universities Name & Engineering ranking in Pakistan & Global engineering ranking \\
\hline National University of Science and Technology, Islamabad & 1 & 279 \\
Pakistan Institute of Engineering and Applied Sciences, Islamabad & 2 & N/A \\
Ghulam Ishaq Khan Institute of Engineering Science and Technology, Swabi & 3 & N/A \\
Institute of Space Technology, Islamabad & 4 & N/A \\
University of Engineering and Technology, Lahore & 5 & 701 \\
Mehran University of Engineering and Technology, Jamshoro & 6 & N/A \\
University of Engineering and Technology, Peshawar & 7 & N/A \\
Air University, Islamabad & 8 & N/A \\
University of Engineering and Technology Taxila & 9 & N/A \\
National Textile University, Faisalabad & 10 & N/A \\
\hline
\end{tabular}

Note: $\mathrm{N} / \mathrm{A}=$ not applicable

The HEC has established the scheme of standards to assess and monitor the quality of engineering education. For that engineering institutes must have to finish the procedure of initial accreditation by Pakistan Engineering Council (PEC), Engineering Accreditation (EA) and Quality Enhancement Certification (QEC) to confirm accreditation, not at an institute level as whole, but only at the program level (Memon et al., 2009). The PEC is responsible for maintaining realistic and global standards of professional competence in engineering education. Therefore, Pakistan became a full signatory of WA on June $21^{\text {st }}, 2017$, which facilitates mobility of Pakistani engineering graduates and professionals throughout the world. In the first stage, graduates from University of Engineering and Technology (UET), Lahore, UET, Taxila, Ghulam Ishaq Khan (GIK) Institute, Swabi and National University of Science and Technology (NUST), Islamabad would benefit from the agreement (Business standards, 2017). The National committee for revised curriculum (NCRC) has also been established to revise and reform the engineering curriculum after every 4 years to meet the global standards and requirements. Since the overall engineering curriculum comprises 33.8-34.6\% non-engineering and 66.2-65.4\% engineering courses (Higher Education Commission Pakistan, 2016).

The Pakistan needs improvement in its basic education infrastructure to build a better foundation for engineering education. It must have to mitigate the problem of governance in the education system and educational budget must be revised, especially in engineering education. Being a strategic and economic partner of China in OBOR initiative, it has built much better cooperation in exchange of students for higher studies. However, it needs betterment in exchange of faculty to China, EU countries and the USA for promoting high-quality research within Pakistani engineering institutes (public/private). Additionally, it must try to establish the campuses of top-ranked universities within the country to develop competence and promote high-quality research.

\subsection{European Countries}

The engineering education in EU countries provides highly professional standards with proven experience and competency in the application of scientific knowledge. Most of universities from EU countries offer two kinds of engineering programs of very different approach among different higher education institutes with no transition from one program to another, only at the cost of one academic year to be lost. The first one is a practice-oriented study comprises compulsory internships in the industry during academic studies. It is a short cycle program which trains students to be ready for work immediately after graduation in a relevant professional field. Second is a long cycle engineering program focusing on basic sciences and prepare engineers for research (Humily, 1997).

Based on program duration, the most of European engineering institutes offer 5 years Master of Studies in Engineering comprises 3 years Bachelors and 2 years Masters, according to the principles of Bologna declaration (Gjengedal \& Schive, 2016). The three years Bachelor of Engineering is offered by either universities or engineering colleges in Italy, Sweden, Denmark, Finland, Germany, France, Portugal and the UK followed by 1 or 2 years Masters. However, Netherlands, Poland, Romania, Spain and Turkey offer 4 years Bachelor of engineering education followed by 1 or 2 years Masters. Since the Bachelor of engineering is Tertiary level in EU education system and before entering students have to take Primary level usually from grade 1 to 4 or 5, the Secondary level-I from grade 5 to 9 or 10 and the Secondary level-II from grade 10 to 13 (Berger-Proßdorf, Educational Systems in Europe). 
The top-ranked engineering institutes in Europe are very selective in their admissions. There exist more than 100 Nobel laureates, who are associated with the well-known institutes of Europe, such as Albert Einstein a most famous alumnus of Eidgenössische Technische Hochschule (ETH) Zurich Switzerland. A large number of international students, libraries, use of information and communication technologies, industry coordinated efforts, budgetary help, job market, advanced research opportunities including the number of Nobel Prize candidates, beneficiaries and the number of citations put the EU educational institutes at the noteworthy positions. The list of top-ranked engineering institutes in Europe and their Global engineering ranking according to Quacquarelli Symonds (QS) World University Ranking for the year 2018 is illustrated in Table 3.

Table 3. Top-ranked engineering institutes in Europe and their global ranking (QS World University Rankings, 2018)

\begin{tabular}{lcc}
\hline Universities Name & Engineering ranking in Europe & Global engineering ranking \\
\hline University of Cambridge UK & 1 & 3 \\
Swiss Federal Institute of Technology Zurich Switzerland & 2 & 4 \\
Imperial College London UK & 3 & 6 \\
Ecole Polytechnique Fédérale de Lausanne (EPFL) Switzerland & 4 & 12 \\
Politecnico di Milano Italy & 5 & 17 \\
Delft University of Technology Netherlands & 6 & 22 \\
Technical University of Munich Germany & 7 & 25 \\
RWTH Aachen University Germany & 8 & 31 \\
Politecnico di Torino Italy & 9 & 33 \\
Technische Universität Berlin Germany & 10 & 39 \\
\hline
\end{tabular}

The standard of EU engineering education is broadly high and improving continuously because of tangency and interchange of good practices among engineering faculties across worldwide. The European Society for Engineering Education commonly known as SEFI encourages information sharing about inflow maturation in engineering among educators, scientists and undergraduate students within Europe. The European Convention for Engineering Deans (ECED) brings all the Deans of educational institutes at a single platform and highlight burning issues, share experiences and develop a system with peers (European Society for Engineering Education, Wikipedia, 2018).

Most of the EU countries spend more than 5\% of their total GDP on education. Netherlands, Sweden, Norway, Finland, Belgium, Austria, France, Italy, UK, Switzerland and Germany dedicated 6.0, 7.0, 6.9, 6.8, 6.6, 6.0, 5.9, 4.5, 5.6, 5.4 and 5.1\% respectively, of their total GDP on the education (List of countries by spending on education as \% of GDP, Wikipedia, 2013-2015). Moreover, the R\&D expenditures as a percentage of GDP for aforesaid countries are 1.973, 3.16, 1.71, 3.17, 2.47, 3.1, 2.256, 1.29, 1.7, 3.0 and 2.87 respectively (List of countries by R\&D spending, Wikipedia, 2013-2015). Additionally, HEIs get huge funding from non-governmental civil society organizations to grow in technical and scientific excellence.

The engineering accreditation has been started since 1934 in France. Later, Engineering Council United Kingdom (EC-UK) was founded in 1981 to keep up guidelines for accreditation procedure in the UK. Afterward, different organizations worked for mutual cooperation and recognition of engineering education. In 2004 European accredited engineer (EUR-ACE) project was set to formulate the principles of accreditation for engineering programs. A definitive framework of principles European Network for Accreditation of Engineering Education (ENAEE) was settled after consultation with stakeholders, which is responsible for awarding EUR-ACE label to accredited engineering programs (European Network for Accreditation of Engineering Education, Wikipedia, 2012). EUR-ACE terms and conditions comprehend all engineering subjects, profiles and ease of free mobility of engineers in Europe. However, the countries follow their own criteria and evaluation system as well (Memon et al., 2009). The EUR-ACE Framework of references does not supplant national norms yet offer a common reference of the system as the explanation behind the award of mutual European quality mark.

Meanwhile, the EU countries are not signatories of WA except UK and Ireland as following the EUR-ACE. The WA depends on uniform accreditation methods autonomously connected by the taking part organizations. However, EUR-ACE framework of common acknowledgment roots from a typical quality name granted by the taking an interest organization in the premise of apportioned gauges and methods. Since the EUR-ACE system is more flexible and adaptable (Augusti, 2009). 


\subsection{USA}

The engineering education in the USA provides non-recreational standards with innovative experience and competency in the application of scientific knowledge. It builds a level of professional skills, safety, environmental consciousness, sense of responsibility and effective communication. The Bachelor of Engineering comprises 4 years like China and Pakistan. First two years core courses followed by two years specialized subjects. The student must decide its major after passing the first year of his degree program. However, it is decided before enrolment in China, Pakistan, and European countries. Before entering to a Bachelor of Engineering student have to take K-12, the term often used in US education refers to twelve years of education, an elementary school for 1 to 5 grades, middle school 6 to 8 grade and high school 9 to 12 grade (Corsi-Bunker, 2002). After engineering graduation, students often start internship or training in an organization for four years to meet the eligibility criteria for appearing in the examination of professional engineer (PE) license. While, in Pakistan after graduation, continuing education courses are needed with professional experience to get PE certification.

In the US more than 35 engineering subjects have been offered in various educational institutes (Graduateshotline). The world's preceding aviation company, the biggest producer of commercial jets and military aircrafts consolidated, Boeing, which has more than 90 nations as a customer, is a perfect example of engineering education benchmarks in the USA (Boenig, Wikipedia, 2018). The list of top-ranked engineering institutes according to Quacquarelli Symonds (QS) World University Ranking in the year 2018 is illustrated in Table 4.

Table 4. Top-ranked engineering institutes in the USA and their global ranking (QS World University Rankings, 2018)

\begin{tabular}{lcc}
\hline Universities Name & Engineering ranking in the USA & Global Engineering ranking \\
\hline Massachusetts Institute of Technology & 1 & 1 \\
Stanford University & 2 & 2 \\
University of California Berkeley & 3 & 11 \\
Harvard University & 4 & 13 \\
Georgia Institute of Technology & 5 & 24 \\
California Institute of Technology (Caltech) & 6 & 26 \\
Carnegie Mellon University & 7 & 31 \\
University of California Los Angeles & 8 & 35 \\
Princeton University & 9 & 38 \\
University of Illinois at Urbana-Champaign & 10 & 46 \\
\hline
\end{tabular}

Expenditure in the education sector is maintained at $5.6 \%$ of total GDP (List of countries by spending on education as a \% of GDP, Wikipedia, 2013-2015). The R\&D spending in higher education is about $2.742 \%$ of the total GDP (List of countries by R\&D spending, Wikipedia, 2013-2015). Since the US expenditure on education as a level of GDP is close to the worldwide average spending. However, its educational institutes are the best in the world rankings.

Engineering accreditation in the USA covers programmatic as well as institutional accreditation. Accreditation Board for Engineering and Technology (ABET) accredits all engineering programs. It has outcome-based structure and accreditation process depends on the faculty, courses of study, facilities, achievements of student, improvements and institutional sense of duty to particular standards of morals and ethics. Graduation from an ABET-accredited program is required for engineers, whoever needed to be authorized (Accreditation, 2018). Besides that, WA was additionally signed between six nations in 1989 covers complex methods of accrediting engineering degree programs. Firstly, it was acquainted with acknowledgment of equivalencies crosswise over both the accreditation process which happens in each nation and in the standards set by that procedure (Lucas, 2014). After its inception in 1989, there are 20 countries as full signatory till 2017. They have consented to make every bit of effort to set out that the engineering licensing and registration bodies in their countries perceive the substantive equality of engineering programs accredited by the alternate signatories. Therefore, engineering education in the USA equips graduates with a number of transferable skills such as problem-solving, decision making, innovation and creativity, teamwork and project management. 


\section{Comparison of Engineering Education}

\subsection{China and Pakistan}

More than 30 engineering disciplines have been offered among 188 institutes of Pakistan. However, in China among 631 engineering institutes, 169 engineering disciplines are offered. China spends approximately $4.3 \%$ of its GDP on education and $2.1 \%$ on research \& development. While Pakistan spends only $2.2 \%$ on education and $0.3 \%$ on R\&D. According to the statistics of Academic Degrees Committee Office of the State Council in 2010, Bachelor of Engineering conferred by Chinese educational institutes accounted for 31.3\% of the total Bachelor programs, while for Master's and doctoral programs in engineering accounted for $36.03 \%$ and $36.4 \%$ respectively (China News, 2010).

Only six Pakistani universities (two in engineering subject) ranked among top 800 universities in the 2018 world rankings published by Quacquarelli Symonds (Rankings of Universities in Pakistan, Wikipedia, 2018). However, more than 40 Chinese universities including Hong Kong and Taiwan ranked among top 500, according to ARWU of Shanghai Jiao Tong University, Times Higher Education (THE) and Quacquarelli Symonds (QS) in 2015/16 ranking lists (Jacob, Mok, Cheng, \& Xiong, 2017). Both countries are a full signatory of WA. However, due to a large number of engineering programs, the accreditation process and maintaining substantial standards is a challenge for China. Pakistan is striving hard to improve annual budget allocated for higher education, especially on engineering education. It needs to revise criteria for appointment, promotion and the demotion of academic staff and set strict implementation of standards in higher education institutes like China. Moreover, it needs to mitigate governance issues at primary and secondary education level. Furthermore, it needs to set up campuses of world-class foreign engineering universities for developing competence and establishing high impact research in engineering education. Being a strategic member of OBOR initiative, it must have strengthened collaboration in education and research with China.

\subsection{China and European Countries}

Europe is a cultural diversity of different countries. The engineering education offered for 3 or 4 years as Bachelors and 1 or 2 years Master's degree program. However, in China, the bachelor program comprises 4 years and 2 or 3 years for Masters. The standard of EU engineering education is broadly high in worldwide and continuously improving due to affiliations and sharing of good practices among engineering faculties throughout the world. Most of the EU countries offer two kinds of engineering programs of very different approach among different higher education institutes, one is research-oriented and another is industry-centric practice-oriented. Moreover, according to Bologna Declaration students, instructors and researchers could move openly from institution to institution crosswise over national adjoins even (Bologna Declaration, Wikipedia, 2018). The educational institutes in Europe have strong industry-academia linkage and students have better exposure towards their professional fields. Most of the EU countries spend more than 5\% on education and $2.5 \%$ on R\&D of their total GDP. Moreover, they get donations from multiple funding agencies and try to engage a lot of foreign students to extend competence. However, in China, the academia-enterprises contact is not sufficiently close. The engineering concepts, building innovations and development outlines are weak. Most of the students aim to wind up as a researcher rather than an engineer. It spends $4.3 \%$ on education and $2.1 \%$ on R\&D of total GDP. Since the Chinese universities are state-run, can hardly get funds from society and other donating agencies (Ding \& Zeng, 2015).

The engineering education in Europe is a student-centered, while in China is a teacher-centered. In EU countries quality-oriented education is delivered. Exams are always an open book and there is no single answer to a question. Open book exams teach you how to find information when you need under a significant amount of pressure. However, in China, the education is examination-based, how to learn when to learn and the training of creative thinking is being neglected (UKessays).

\subsection{China and the USA}

The engineering education in the USA focuses on basic engineering knowledge, intellectual thinking, utilizing knowledge in the work and ability to cooperate with partners. It is based on professional standards of engineering abilities. However, Chinese engineering education tends to provide basic knowledge rather than professional abilities. The curricula of Industrial Engineering (IE) and Mechanical Engineering (ME) were compared between Worcester Polytechnic Institute (WPI), USA and Beijing Jiao Tong University (BJTU), China. In WPI, the proportion of courses about the major contained 33\% for IE and 40\% for ME. While, in BJTU, the proportion of major courses in IE and ME were $16.8 \%$ and $27.6 \%$ respectively (Jie et al., 2009).

In China, the task of teachers is delivering facts to students and a student tries to listen and accept the knowledge. 
On the contrary, in the USA, the teachers are more likely to be instructors or aspirators, that would encourage students to take part in the learning/studying process. The interaction between instructors and students is quite common and normal, but we can hardly find any atmosphere of encouraged discussion among teachers and students at class in China. Moreover, the USA spends more on education, R\&D as a proportion of its GDP compared to China. Additionally, the higher education institutes are also supported by non-governmental civil society organizations.

\section{Overall Comparison}

Since, evaluating the current status of engineering education in China, Pakistan, Europe, and USA, the USA has long been remained at first in the world. Unpredictably, the advancement of engineering education in Germany, France, Italy, Netherlands and the United Kingdom remained slow after 2010, as shown in Figure 1. The Chinese educational institutes are improving constantly since 2006 and the engineering education in Pakistan is also improving with the cooperation of China, Europe, and the USA. However, only six Pakistani universities (two in engineering subject) have made it to be ranked among top 800 universities of the world (Rankings of Universities in Pakistan, Wikipedia, 2018).

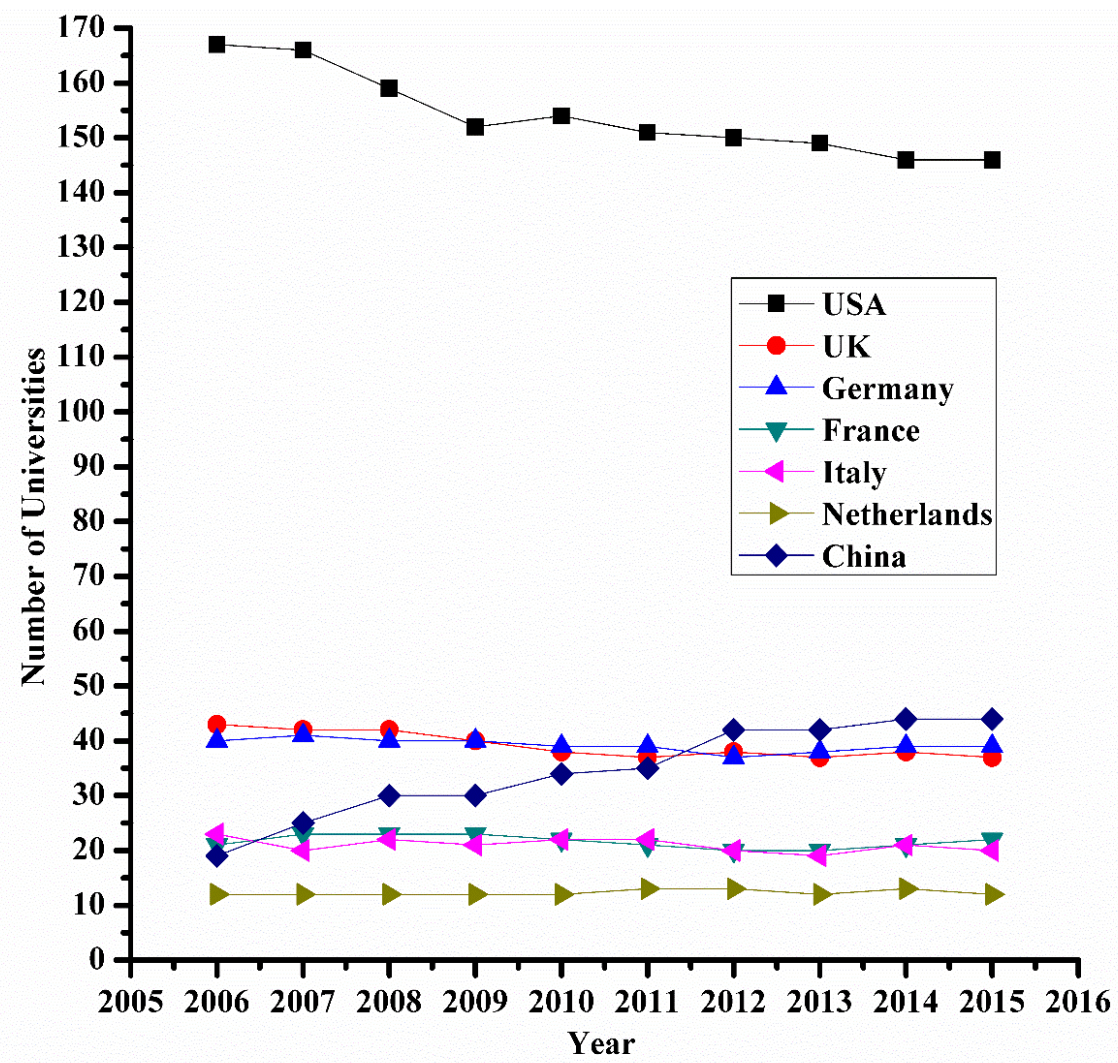

Figure 1. Number of universities in top 500 ARWU list for the period of 2006-2015 (Reddy, Xie, \& Tang, 2016)

The Science and Engineering Indicators 2014 states that, out of world's 827,705 scholarly articles distributed in 2011, the scientists from the 28 European Union nations delivered 254,482 (31\%) articles, the United States $212,394(26 \%)$ articles and China 89,894 (11\%) articles. Among the EU countries, Germany delivered the highest number of articles with 46,259 followed by the UK with 46,035. The overall number of articles published by authors from China upraised from $3 \%$ to $11 \%$ of worldwide research turnout. In addition, the articles authored by Chinese scholars were grown by 15\% every year from 2001 to 2011 . However, the share of Chinese scholarly articles cited by worldwide researchers has fallen in the course of recent decades intimating the increased research outcomes in China are being mostly utilized within its own borders. At the same time, the quantity of scholarly articles has been declined in EU countries and the US too. Of the 200,000 doctoral graduates in science and engineering granted across the world in 2010, around 33,000 were conceded by universities in the USA, 31,000 in China, 12,000 in Germany and 11,000 in the UK (Kigotho, 2014).

Considering the above indicators, the USA and Germany have progressed successively in engineering education 
by spending the normal share of their GDP on education, research and development, as shown in Figure 2. While the China being a largest producer of engineering graduates in a vast number of engineering programs and signatory of WA has crucial challenges to meet the quality of engineering education. In addition, the success of OBOR initiative largely depends on the engineering education. Therefore, further work is needed by China to deeply investigate and follow the educational structure of US and Germany to meet the international standards. Meanwhile, the OBOR strategy brings diverse societies on a single platform. It will create new opportunities for various political, economic and social stakeholders. Therefore, further work on the political, cultural and social aspects of OBOR strategy is also proposed.

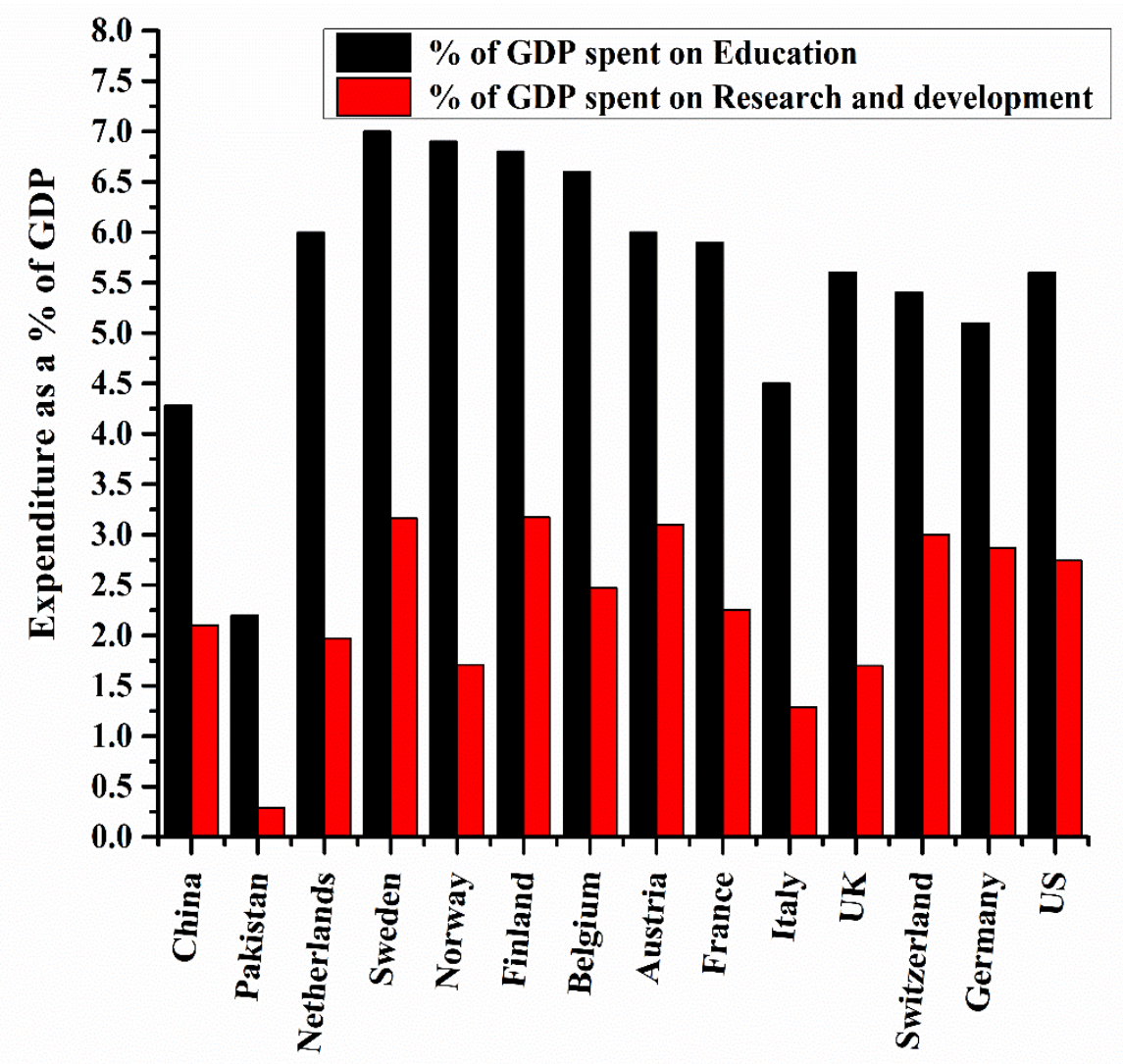

Figure 2. Education and R\&D expenditure as a percentage of GDP of different countries (List of countries by R\&D spending, Wikipedia, 2013-2015)

\section{Conclusion}

The engineering education of Pakistan, EU countries, and the USA is studied and compared with Chinese engineering education. The USA and Germany have progressed successively in engineering education by spending the normal share of their GDP on education, R\&D. So, China should follow the education system of US and Germany to build magnificence in engineering education. Furthermore, it should update its engineering curricula and pedagogy from theoretical knowledge to practice-oriented and outcome based. It also needs to strengthen industry-academia relationship focusing on funding opportunities. The restoration of the ancient Chinese Silk Road as OBOR strategy is the biggest scoop of the physical connection between China, Europe, Western Asia, Southeast Asia and Africa. The OBOR initiative will connect China and the world and will create world's largest economic, trade, financing and educational platform, with Pakistan and European countries being major stakeholders with more than 60 countries as beneficiaries. Meeting the above challenges will build excellence of engineering education in China and will allow it to export its expertise in engineering education to the developing countries through OBOR platform. Moreover, it will help to develop a unified engineering accreditation model to address global competencies. 


\section{Acknowledgments}

This study was supported by the Teaching Reform Program for "New Engineering" Research and Practice (xgk2017040117), Teaching Reform Program in Graduate Education (G-JG-PT201603), Centre for Teaching and Learning Development of Beijing University of Chemical Technology and "One Belt, One Road" National Talent Training Project of Beijing, China.

\section{Conflicts of Interest}

The authors declare no conflict of interest.

\section{References}

Accreditation. (2018). Retrieved from http://www.abet.org/accreditation/

Alves, A. C., Kahlen, F. J., Flumerfelt, S., \& Manalang, A. B. S. (2013). Comparing Engineering Education Systems Among USA, EU, Philippines and South Africa. Paper presented at the ASME 2013 International Mechanical Engineering Congress and Exposition. https://doi.org/10.1115/IMECE2013-63254

Yusufzai, A. (2016). Budget 2016-17: Rs. 84 Bln for Education, Rs. 79.5 Bln for Higher Education, Pakistan. Retrieved from http://propakistani.pk/2016/06/03/budget-2016-17-rs-84-bln-for-education-rs-79-5-bln-for higher education/

Corsi-Bunker, A. (2002). Guide to the Education System in the United States. Retrieved from http://docplayer.net/20649730-Guide-to-the-education-system-in-the-United-states.html

Rahman, A. (2011). Advances in Engineering Education in Pakistan. Retrieved from https://tribune.com.pk/ story/170491/advances-in-engineering-education-in-pakistan--i/

Augusti, G. (2009). EUR-ACE: The European Accreditation System of Engineering Education and its Global Context. Engineering Education Quality Assurance: A Global Perspective (pp. 41-49). Boston, MA: Springer US.

Bachelors Portal. Study Options in the USA. Retrieved from https://www.bachelorsportal.com/studyoptions/26977 8981/aerospace-engineering-united-states.html

Bai, J., Hu, L., Li, Y., Tian, Z., Xie, L., Wang, L., \& Xie, H. (2013). The Progress of CDIO Engineering Education Reform in Several China Universities: A Review. Procedia - Social and Behavioural Sciences, 93(1), 381-385.

Boeing. (2018). In Wikipedia the free encyclopedia. Retrieved from https://en.wikipedia.org/wiki/Boeing.

Bologna Declaration. (2018). In Wikipedia, the Free Encyclopaedia. Retrieved from http://en.wikipedia.org/wiki/ Bologna_declaration

Business Standards. (2017). Retrieved from http://www.businessstandard.com/article/news-ani/pakistan-becomes -full-signatory-of-washington-accord-117062201418_1.html

China News. (2010). Retrieved from http://www.china.org.cn/

Ding, L., \& Zeng, Y. (2015). Evaluation of Chinese Higher Education by TOPSIS and IEW-The Case of 68 Universities Belonging to the Ministry of Education in China. China Economic Review, 36, 341-358. https://doi.org/10.1016/j.chieco.2015.05.007

European Society for Engineering Education. (2018). In Wikipedia, the Free Encyclopedia. Retrieved from http://e n.wikipedia.org/wiki/European_Society_for_Engineering_Education

European Network for Accreditation of Engineering Education. (2012). In Wikipedia, the Free Encyclopedia. Retrieved from

http://en.wikipedia.org/wiki/European_Network_for_Accreditation_of_Engineering_Education

Fan, J., \& Zhang, C. (2015). A Study of the Rate of Return to Higher Engineering Education in China. International Journal of Educational Development, 42, 106-114. http://doi.org/10.1016/j.ijedudev.2015.04.010

Gjengedal, A., K., \& Schive, T. (2016). Reconstruction Higher Education in Norway Consequences for Engineering Education. Proceedings of International Conference on Engineering Education and Research, Western Sydney University, Parramatta Campus, Sydney, Australia. ISBN 978-0-64695724-1

Graduateshotline. Retrieved from https://www.graduateshotline.com/

Higher Education Commission Pakistan. (2016). Retrieved from 
http://hec.gov.pk/english/serivces/universities/cr/Pages/default.aspx.

Humily, G. (1997). Science and Engineering Education in Europe. Frontiers the Interdisciplinary Journal of Study Abroad, 3, 30-34.

Jacob, W. J., Mok, K. H., Cheng, S. Y., \& Xiong, W. (2017). Changes in Chinese Higher Education: Financial Trends in China, Hong Kong, and Taiwan. International Journal of Educational Development, 58, 64-85. https://doi.org/10.1016/j.ijedudev.2017.03.006

James, J., \& Chen, H. (2016). A Review of Key Trends in Chinese Education. Trends in Chinese Education, $\left(1^{\text {st }}\right.$ Edition), pp. 20-22, 9781317749423.

Jiaju, B. (2009). Engineering Accreditation in China. Chinese Education \& Society, 42(1), 105-112. https://doi.org/10.2753/CED1061-1932420109

Jie, B., Zhang, X., Chen, J., Sun, M., Yu, F., \& Zhou, Z. (2009). Comparative Study on Engineering Education in China and USA. Bachelor of Science, USA. (Bachelor's thesis Worcester Polytechnic Institute Massachusetts USA). Retrieved from https://web.wpi.edu/Pubs/E-project/Available/E-project-082509224412/unrestricted/ final_report.pdf

Lucas, J. (2014). Retrieved from https://www.livescience.com/47499-what-is-engineering.html

Khattak, K. (2016). MIT Technology Review Pakistan. Retrieved from http://www.technologyreview.pk/unloc king-big-data-for-electioneering/

Li, F., Morgan, W. J., Li, F., Morgan, W. J., Li, F., \& Morgan, W. J. (2011). Private Higher Education in China: Problems and Possibilities. Higher Education Reform in China: Beyond the Expansion. China policy series. ERIC, ISBN-978-0-4155-6413-7.

List of Countries by R\&D Spending. (2018). In Wikipedia, the Free Encyclopaedia. Retrieved from https://en. wikipedia.org/wiki/List_of_countries_by_research_and_development_spending

List of Countries by Spending on Education as \% of GDP. (2018). In Wikipedia, the Free Encyclopedia. Retrieved from https://en.wikipedia.org/wiki/List_of_countries_by_spending_on_education_\%_of_GDP.

List of Universities in Pakistan. (2018). In Wikipedia, the Free Encyclopaedia. Retrieved from http://en.wikipedia.org/wiki/List of universities in Pakistan

McAuley, L., \& Tiernan, S. (2012). Irish and Chinese Students' College Experience on a Joint Engineering Programme. Paper presented at SEFI $4^{\text {th }}$ International Conference on Global Mobility and International Cooperation, Greece.

Memon, J. A., Demirdogen, R. E., \& Chowdhry, B. S. (2009). Achievements, Outcomes, and Proposal for Global Accreditation of Engineering Education in Developing Countries. Procedia-Social and Behavioural Sciences, 1(1), 2557-2561. https://doi.org/10.1016/j.sbspro.2009.01.451

Ministry of Education China. (2016). Retrieved from http://www.moe.edu.cn/s78/A03/moe_560/jytjsj_2015

Olcay, G. A., \& Bulu, M. (2016). Is Measuring the Knowledge Creation of Universities Possible? A Review of University Rankings. Technological Forecasting \& Social Change, 123, 153-160.

QS World University Rankings for Engineering and Technology. (2018). Retrieved from http://www.topuniversities.com/university-rankings/university-subject-rankings/2018/engineering-technology

Rankings of Universities in Pakistan. (2018). In Wikipedia, the Free Encyclopaedia. Retrieved from http://en.wikip edia.org/wiki/Rankings_of_universities_in_Pakistan

Reddy, K. S., Xie, E., \& Tang, Q. (2016). Higher Education, High-Impact Research, and World University Rankings: A Case of India and Comparison with China. Pacific Science Review B: Humanities and Social Sciences, 2(1), 1-21. https://doi.org/10.1016/j.psrb.2016.09.004

Reviewmycdr. (2016). Retrieved from http://reviewmycdr.com/china-got-washington-accord-accreditation/

Ryan, J., Kang, C., Mitchell, I., \& Erickson, G. (2009). China's Basic Education Reform: An Account of an International Collaborative R\&D Project. Asia Pacific Journal of Education, 29, 427-441. https://doi.org/10.1080/02188790903308902

Sonmez, M. (2014). The Role of Technology Faculties in Engineering Education. Procedia-Social and Behavioural Sciences, 141, 35-44. https://doi.org/10.1016/j.sbspro.2014.05.009

Berger-Proßdorf, T. Educational Systems in Europe. Retrieved from http://mtprof.msun.edu/Win1996/ 
TamaraBP.html

Jinchen, T. (2016). One Belt and One Road: Connecting China and the World. Retrieved from http://www.mcki nsey.com/industries/capital-projects-and-infrastructure/our-insights/one-belt-and-one-road-connecting-china -and-the-world.

UKessays. Retrieved from https://www.ukessays.com/essays/education/differences-of-education-between-china-and-america-educatio n essay. php

US News \& World Reports. (2015). Retrieved from www.usnews.com/education/best-globaluniversities/china/engineering

Kigotho, W. (2014). China's Rapid rise in global science and engineering. Retrieved from http://www.universityw orldnews.com/article.php?story=201402271524 09830

Yu, S. O. (2016). One Belt, One Road: Enhancing Malaysian Students Mobility. European Journal of Education Studies, 2(3).

Zhao, X. (2017). China has World's Largest Higher Education System, Daily China. Retrieved from http://www.chinadaily.com.cn/china/2017-09/28/content_32606890.html.

\section{Copyrights}

Copyright for this article is retained by the author(s), with first publication rights granted to the journal.

This is an open-access article distributed under the terms and conditions of the Creative Commons Attribution license (http://creativecommons.org/licenses/by/4.0/). 